\title{
Impact of Diabetes Mellitus and Obesity on Male Infertility in Iraqi patients
}

\author{
Gummar Ouda Zamil M sc*, Basil OM Saleh Ph D**, \\ Kifah Hamdan Abdulghafour PhD*** \\ *Al-Amam Ali Hospital, Baghdad \\ ** Department of Biochemistry, College of Medicine, Baghdad University \\ ***Department of Pathology, College of Medicine, Baghdad University
}

\begin{abstract}
Background: Several studies have highlighted the high prevalence of low Total Testosterone (TT) and Free Testosterone (FT) in men with type 2 diabetes and demonstrated links with visceral adiposity, insulin resistance and $\mathrm{HbA}_{1} \mathrm{C}$. The aim of this study is to evaluate the role of diabetes alone and the association of diabetes and obesity on prevalence of infertility in Iraqi male.

Subjects and Methods: This case-control study was carried out at Al-Amam Ali Hospital and The Specialized Center For Diseases of Endocrines \& Diabetes, Baghdad-Iraq, during the period from December 2011 to April 2012. It consisted of 63 male patients with type 2 Diabetes Mellitus (DM) and 25 healthy controls. Diabetic patients were further subdivided into the three groups according to their BMI as: 1. Diabetic Normo BMI $\operatorname{group}\left(n=28, B M I 18-25 \mathrm{~kg} / \mathrm{m}^{2}\right)$, 2. Diabetic Overweight group $\left(n=11 \quad B M I 25-30 \mathrm{~kg} / \mathrm{m}^{2}\right)$, and 3. Diabetic Obese group $\left(n=24 ; B M I\right.$ was over than $\left.30 \mathrm{~kg} / \mathrm{m}^{2}\right)$. Investigations included serum measurements of fasting serum glucose, $\mathrm{HbA}_{7} \mathrm{C}$ (using spectrophotometric technique), follicle stimulating hormone FSH, lutilizing hormone LH, prolactin, free testosterone by using ELISA technique in patient groups and healthy controls.

Results: The mean $( \pm S D)$ values of $H b A_{1} C$ of diabetic obese, diabetic overweight, and diabetic normoBMI patients were higher than that of healthy controls(for all; $P<0.0001$ ). Also, the mean values of $\mathrm{HbA}_{1} \mathrm{C}$ of diabetic normoBMI was significntly increased compared to that of diabetic obese $(P<0.025)$. However, there was no significant difference in mean value of $\mathrm{HbA}_{1} \mathrm{C}$ between diabetic overweight and diabetic obese. Serum levels of FSH, LH, and prolactin did not differ significantly among the patient groups and controls. Serum mean value of free testosterone of diabetic obese patients was significantly lower than that of diabetic overweight $(P<0.016)$ and healthy controls $(P<0.001)$, but did not differ significantly between the diabetic overweight and diabetic normoBMI with control group. The results also showed that there was significant negative correlation between the serum free testosterone levels and the $\mathrm{HbA}_{1} \mathrm{C}$ values in diabetic obese group $(r=-0.455, P<0.025)$.

Conclusion: This study revealed that association of diabetes mellitus and obesity but not diabetes alone have significant impact on deficiency of free testosterone and consequent sub fertility in male not suffering from primary or secondary causes of infertility.
\end{abstract}

Key Words: Diabetes mellitus, obesity, infertility, free testosterone.

\section{Introduction:}

Diabetes mellitus is a disease which is characterized by increased blood glucose levels known as hyperglycemia due to abnormality either in insulin secretion, insulin action, or both [1]. There are two types of diabetes mellitus; Type 1 diabetes and Type 2 diabetes.

Type I diabetes is a multifactorial autoimmune disease due to severe insulin deficiency that is influenced by environmental and genetic factors. Type 2 diabetes is a non-immune disorder with varying degrees of insulin resistance and impaired insulin secretion usually associated with obesity [2]. Type 2 diabetes (which accounts for over $95 \%$ of diabetes worldwide) results from a complex gene environment interaction for which several risk factors, such as age, sex, ethnicity, family history, obesity, and hypertension, are well documented [3].

Obesity is defined by the Centers for Disease Control as a body mass outside the range of that which has been determined to predict healthy outcomes; a determination made through the use of the body mass index (BMI), which is based on height and weight. The BMI classification by the National Heart, Lung, and Blood Institute for adults (age 18-85) defines an individual as being overweight for BMI between 25 and $29.9 \mathrm{~kg} / \mathrm{m}^{2}$, and obese for BMI greater than $30 \mathrm{~kg} / \mathrm{m}^{2}$ [4]. In obesity the initial deposition of triglycerides occurs in subcutaneous adipose tissue and as this increases in size insulin resistance will rise and limit further subcutaneous lipid accumulation reference [5]. 
Infertility is defined as inability to achieve conception within one year [6]. The couple who has not conceived after 12 months is the lowest reference limit for Time to Pregnancy (TTP) by the world health organziation [7]. Infertility is primary if there has never been a conception and secondary if there has been at least one conception. Subfertility and subfecundity are also used in some studies as synonyms to infertility [8].

Diabetes Mellitus (DM) is known to cause many systemic complications and male infertility [9]. In a retrospective analysis, it has been found a very high prevalence of subfertility (51\%) among diabetic patients [10]. Several studies have highlighted the high prevalence of low Total Testosterone (TT) and Free Testosterone (FT) in men with type 2 diabetes and demonstrated links with visceral adiposity, insulin resistance, $\mathrm{HbA}_{1} \mathrm{C}$, and symptoms of hypogonadism such as Erectile Dysfunction (ED) and low sexual desire [11].

Testosterone production is regulated by the hypothalamic-pituitary-testicular (HPT) axis. Testosterone deficiency can result from a disease of the testes (primary hypogonadism), defects of the pituitary or hypothalamus (secondary hypogonadism), or a combination of primary and secondary causes [12]. Measuring leuteinizing hormone ( $\mathrm{LH})$ and follicle-stimulating hormone (FSH) levels can distinguish between these etiologies [12]. Men with primary hypogonadism are expected to have low testosterone in association with elevated LH and FSH levels. By comparison, men with secondary hypogonadism also called hypogonadotropic hypogonadism will have low testosterone and low or normal LH and FSH levels [12].

Observational studies consistently show that men with diabetes have lower TT levels than nondiabetic controls [13]. At least $25 \%$ of men with T2DM have evidence of secondary hypogonadism, and an additional $4 \%$ have primary hypogonadism [14]. Low testosterone concentrations in men have been shown to be associated with obesity and T2DM [15]. Plasma-free testosterone, total testosterone and sex hormone-binding globulin are low in obesity and recover in proportion to the degree of weight loss [16]. The pathophysiology of low plasma testosterone in men with T2DM as well as the broader neuroendocrine signalling processes by which the metabolic milieu influences reproduction remains poorly understood [17].

\section{Subjects an methods :}

This case-control study was carried out at Al-Amam Ali Hospital and The Specialized Center For Diseases of Endocrines \& Diabetes, Baghdad- Iraq, during the period from December 2011 to April 2012 . It consisted of 63 male patients with type 2 Diabetes Mellitus (DM) and 25 healthy controls . Diabetic patients were further subdivided into the following groups according to their BMI as: 1. Diabetic Normo BMI group that consisted of 28 diabetic male patients with BMI range between $18-25 \mathrm{~kg} / \mathrm{m}^{2}$ and aged ( $40-61$ years ), 2 . Diabetic Overweight group that consisted of 11 diabetic male patients with BMI range between $25-30 \mathrm{~kg} / \mathrm{m}^{2}$ and aged ( 40 - 63 years ), and 3. Diabetic Obese group that included 24 diabetic male patients; their BMI was over than $30 \mathrm{~kg} / \mathrm{m}^{2}$ and aged (40 - 62 years ). The control group involved 25 heathy fertile men their BMI between was $18-25 \mathrm{~kg} / \mathrm{m}^{2}$, and ages between ( $40-63$ years ). Each control subject must has had normal fasting serum glucose, $\mathrm{HbA}_{1} \mathrm{C}$ value and without any history of diabetes mellitus, primary and secondary causes of infertility.

Blood sample was taken in the fasting state from peripheral vein of each patient and control. The blood divided into two fractions; one in EDTA anticoagulant tube for $\mathrm{HbA}_{1} \mathrm{C}$ measurement and other in plain tube . The plain tube blood sample allows to clot for 30 minutes, centrifuged at 3000 r.p.m, and the separated serum was stored at $-20{ }^{\circ} \mathrm{C}$ until the day of the following investigations; Fasting serum glucose, lipid profile parameters including total cholesterol(Tch), triglyceride(TG), high density lipoprotein-cholesterol(HDL-C) and low density lipoprotein-cholesterol(LDL-C), Free testosterone(FF), FSH , LH and prolactin .

SPSS version 18 for window was used for all statistical analysis . Statistical significance was assessed by ANOVA and student t-test. The linear regression test was applied for the correlation between different parameters, and the significance of the r-value was checked using t-test. P-value of less than 0.05 was considered significant.

\section{Results:}

Table 1 shows the mean $( \pm \mathrm{SD})$ values of clinical data for diabetic ( obese, overweight, normoBMI ) patients and healthy controls. The results revealed that there were no significant differences in the mean $( \pm \mathrm{SD})$ values of age for diabetic groups (obese, overweight, normoBMI) and healthy controls. The mean values of BMI of diabetic obese $\left(33.40 \pm 3.33 \mathrm{~kg} / \mathrm{m}^{2}, \mathrm{P}<0.0001\right)$ and diabetic overweight $\left(27.85 \pm 1.24 \mathrm{~kg} / \mathrm{m}^{2}, \mathrm{P}<0.001\right)$ groups were significantly higher than that of diabetic normoBMI $\left(22.49 \pm 2.14 \mathrm{~kg} / \mathrm{m}^{2}\right)$ and of healthy controls $\left(22.06 \pm 1.62 \mathrm{~kg} / \mathrm{m}^{2}\right)($ Table 1$)$.

Table 2, shows the mean $( \pm \mathrm{SD})$ values of FSG \& $\mathrm{HbA}_{1} \mathrm{C}$ of diabetic obese, diabetic overweight, diabetic normoBMI patients and healthy controls . The results revealed that the mean values of FSG and $\mathrm{HbA}_{1} \mathrm{C}$ of diabetic obese $(11.70 \pm 4.23 \mathrm{mmol} / \mathrm{l}, 6.97 \pm 1.22 \%)$, diabetic overweight $(13.05 \pm 6.09 \mathrm{mmol} / \mathrm{l}, 6.66 \pm 0.90 \%)$, and diabetic normoBMI $(15.05 \pm 4.40 \mathrm{mmol} / \mathrm{l}, 7.84 \pm 1.45 \%)$ were significantly higher than those of healthy controls $(5.14 \pm 0.75 \mathrm{mmol} / \mathrm{l}, 5.27 \pm 0.15 \%)($ for all $\mathrm{P}<0.0001)$. Also, the mean values of FSG and $\mathrm{HbA}_{1} \mathrm{C}$ of 
diabetic normoBMI were significntly increased compared to those of diabetic obese $(\mathrm{P}<0.008, \mathrm{P}<0.025$; respectively).However, there were no significant differences in the mean $( \pm \mathrm{SD})$ values of FSG between diabetic overweight and each of diabetic obese and diabetic normoBMI and in mean value of $\mathrm{HbA}_{1} \mathrm{C}$ between diabetic overweight and diabetic obese.

Table 3, shows the mean $( \pm \mathrm{SD})$ values of LH, FSH, Prolactin and Free Testosterone for diabetic (obese, overweight, normoBMI ) patients and healthy controls .The mean $( \pm \mathrm{SD})$ values of serum LH, FSH did not differ significantly between patient groups and healthy controls as well as patient groups themselves .The results revealed that the mean values of serum prolactin were significantly increased in diabetic obese $(7.28 \pm 4.16$ $\mathrm{ng} / \mathrm{ml}, \mathrm{p}<0.001)$ and diabetic overweight $(9.06 \pm 9.23 \mathrm{ng} / \mathrm{ml}, \mathrm{p}<0.008)$ when compared with that of diabetic normoBMI $(3.70 \pm 2.72 \mathrm{ng} / \mathrm{ml})$. However, the mean $( \pm \mathrm{SD})$ value of serum prolactin did not differ significantly among other groups. With regard to free testosterone, the mean $( \pm \mathrm{SD})$ value of serum free testosterone levels in diabetic obese $(3.54 \pm 1.79 \mathrm{Pg} / \mathrm{ml})$ was significantly decreased in comparison with that of diabetic overweight $(5.20 \pm 1.82 \mathrm{Pg} / \mathrm{ml}, \mathrm{p}<0.016)$ and healthy controls $(5.79 \pm 2.71 \mathrm{Pg} / \mathrm{ml}, \mathrm{p}<0.001)$. Furthermore, the mean $( \pm \mathrm{SD})$ value of serum free testosterone of diabetic overweight and diabetic normoBMI were lower than that of healthy controls, but did not reach the significant level. This study also revealed that there was significant negative correlation between serum free testosterone levels and the values of $\mathrm{HbA}_{1} \mathrm{C}$ in diabetic obese patients $(\mathrm{r}=-0.455$, $\mathrm{P}<0.025)$. Also, there was significant negative correlation between serum free testosterone levels and serum $\mathrm{TG}$ concentrations in diabetic overweight $(\mathrm{r}=-0.645, \mathrm{P}<0.032)$.

Table-1- The mean $( \pm \mathrm{SD})$ values of clinical data for Diabetic ( Obese, Overweight, NormoBMI ) patients and healthy controls .

\begin{tabular}{|c|c|c|c|c|}
\hline Parameter & $\begin{array}{l}\text { Diabetic Obese } \\
\mathrm{n}=(24)\end{array}$ & $\begin{array}{l}\text { Diabetic } \\
\text { Overweight } \quad \mathrm{n}= \\
\text { (11) }\end{array}$ & $\begin{array}{ll}\text { Diabetic } & \text { Normal } \\
\text { BMI } & n=(28)\end{array}$ & $\begin{array}{ll}\text { Control } & \text { Normal } \\
\text { BMI } & n=(25)\end{array}$ \\
\hline Age (years) & $\begin{array}{c}50.50 \pm 7.90 * * * \\
(40-62)\end{array}$ & $\begin{array}{c}50.81 \pm 7.04 * * * \\
(40-63)\end{array}$ & $\begin{array}{c}50.78 \pm 7.06 * * * \\
61)\end{array}$ & $\begin{array}{c}50.45 \pm 7.11 * * * \\
63)\end{array}$ \\
\hline BMI $\left(\mathrm{kg} / \mathrm{m}^{2}\right)$ & $\begin{array}{c}33.40 \pm 3.33 \\
43.9)\end{array}$ & $\begin{array}{c}27.85 \pm 1.24 *(25.4- \\
29.1)\end{array}$ & $\begin{array}{c}22.49 \pm 2.14 * * * \\
(18.5-24.8)\end{array}$ & $\begin{array}{c}22.06 \pm 1.62 * * * \\
(19.2-24.6)\end{array}$ \\
\hline $\begin{array}{l}\text { Waist } \\
\text { circumference } \\
\text { (inche) }\end{array}$ & $\begin{array}{c}45.00 \pm 3.52 *(40.0- \\
53.0)\end{array}$ & $\begin{array}{c}37.81 \pm 3.08 * * \\
39.8)\end{array}$ & $\begin{array}{c}34.73 \pm 2.17 * * * \\
(29.0-38.0)\end{array}$ & $\begin{array}{c}34.42 \pm 2.19 * * * \\
(30.0-37.5)\end{array}$ \\
\hline
\end{tabular}

-BMI: body mass index .

* t-test revealed significant difference between diabetic obese and each of diabetic overweight, diabetic normoBMI and healthy control as well as between diabetic overweight and each of diabetic normoBMI and healthy control $(p=0.0001)$.

** t-test revealed significant difference between diabetic overweight and each of diabetic normoBMI and healthy control $(p=0.001)$.

*** not significant

Table-2- The mean $( \pm \mathrm{SD})$ values of FSG \& $\mathrm{HbA}_{1} \mathrm{C}$ with parameters for Diabetic (Obese, Overweight, NormoBMI ) patients and healthy controls .

\begin{tabular}{|c|c|c|c|c|}
\hline Parameter & $\begin{array}{l}\text { Diabetic Obese } \\
\mathbf{n}=(24)\end{array}$ & $\begin{array}{l}\text { Diabetic } \\
\text { Overweight n= } \\
\text { (11) }\end{array}$ & $\begin{array}{l}\text { Diabetic Normal } \\
\text { BMI } \quad n=(28)\end{array}$ & $\begin{array}{ll}\text { Control } & \text { Normal } \\
\text { BMI } & n=(25)\end{array}$ \\
\hline FSG $(\mathrm{mmol} / \mathrm{l})$ & $\begin{array}{c}11.70 \pm 4.23^{*}(* *) \\
(5.1-24.6) \\
\end{array}$ & $\begin{array}{c}13.05 \pm 6.09 * * * \\
(4.9-20.5) \\
\end{array}$ & $\begin{array}{c}15.05 \pm 4.40 \\
23.5)\end{array}$ & $\begin{array}{r}5.14 \pm 0.75^{*} \\
6.7) \\
\end{array}$ \\
\hline $\mathrm{HbA}_{1} \mathrm{C}(\%)$ & $\begin{array}{c}6.97 \pm 1.22 *(* *) \\
(5.4-9.1)\end{array}$ & $\begin{array}{c}\text { 6.66 } \pm 0.90 * * * * \\
(5.3-8.3)\end{array}$ & $\begin{array}{c}7.84 \pm 1.45 *(* *) \\
(5.3-11.1)\end{array}$ & $\begin{array}{c}5.27 \pm 0.15 *(5.0- \\
5.6)\end{array}$ \\
\hline
\end{tabular}

* t-test revealed significant difference between; diabetic obese and healthy control, diabetic overweight and healthy control, diabetic normoBMI and healthy control $(p=0.0001)$.

** t-test revealed significant difference in FSG between diabetic obese and diabetic normoBMI $(\mathrm{p}=0.008)$, in $\mathrm{HbA}_{1} \mathrm{C}$ between; diabetic obese and diabetic normoBMI $(\mathrm{p}=0.025)$, diabetic overweight and diabetic normoBMI $(\mathrm{p}=\mathbf{0 . 0 1 7})$.

*** not significant 
Table -3- The mean $( \pm \mathrm{SD})$ values of LH, FSH, Prolactin, Leptin and Free Testosterone for Diabetic ( Obese,

Overweight, NormoBMI ) patients and healthy controls .

\begin{tabular}{|c|c|c|c|c|}
\hline Parameter & $\begin{array}{l}\text { Diabetic Obese } \\
n=(24)\end{array}$ & $\begin{array}{l}\text { Diabetic } \\
\text { Overweight } n= \\
\text { (11) }\end{array}$ & $\begin{array}{l}\text { Diabetic Normal } \\
\text { BMI } \quad n=(28)\end{array}$ & $\begin{array}{ll}\text { Control } & \text { Normal } \\
\text { BMI } & n=(25)\end{array}$ \\
\hline LH (mIU/ml) & $3.17 \pm 1.96 * * *$ & $2.88 \pm 1.32 * * *$ & $4.10 \pm 3.51 * * *$ & $4.44 \pm 2.94 * * *$ \\
\hline FSH (mIU/ml) & $6.43 \pm 4.05 * * *$ & $4.32 \pm 2.04 * * *$ & $8.04 \pm 6.95 * * *$ & $6.81 \pm 7.40 * * *$ \\
\hline Prolactin (ng/ml) & $7.28 \pm 4.16 *$ & $9.06 \pm 9.23 * *$ & $3.70 \pm 2.72 * * *$ & $8.74 \pm 8.21 * *$ \\
\hline $\begin{array}{l}\text { Free Testosterone } \\
(\mathrm{pg} / \mathrm{ml})\end{array}$ & $3.54 \pm 1.79 * *$ & $5.20 \pm 1.82 * * *$ & $5.00 \pm 3.44 * * *$ & $5.79 \pm 2.71 *$ \\
\hline
\end{tabular}

* t-test revealed significant difference in Prolactin between diabetic obese and diabetic normoBMI, in Free testosterone between diabetic obese and healthy control $(p=0.001)$.

** t-test revealed significant difference in Prolactin between; diabetic overweight and diabetic normoBMI $(p=0.008)$, diabetic normoBMI and healthy control $(p=0.003)$, in Free testosterone between diabetic obese and diabetic overweight $(p=0.016)$. *** not significant .

\section{Discussion:}

The results of this study showed that the mean $( \pm \mathrm{SD})$ value of FSG and $\mathrm{HbA}_{1} \mathrm{C}$ were significantly increased in diabetic patient groups compared with healthy controls( Table -2 ). These results can be explained by poor glycaemic control in diabetes patients with persistent excess of plasma glucose that would overwhelm the glycolytic enzymes. The excess glucose would then be shunted into other metabolic pathways such as glycosylation, glucose autoxidation, and glucosamine pathway, forming reactive oxygen species (ROS) [18].

Another cause can be contributed to decline in $\beta$-cell function leading to reduced insulin production at normal concentration, non-esterified fatty acid (NEFA) is a source of energy for

$\beta$-cell. If non-esterified fatty acid is elevated for prolonged period is toxic to the $\beta$-cell, causing decreased glucose induced insulin secretion [19], impaired insulin gene expression, and increased cell death. This is called lipotoxicity, and is another cause of progressive decline in

$\beta$-cell function leading to reduced insulin production seen in diabetes patients with poor glycaemic control [19]. Additionally, the level of $\mathrm{HbA}_{1} \mathrm{C}$ in a blood sample provides a glycemic history of the previous 70 days. "American Diabetic Association" (ADA) recommends measuring $\mathrm{HbA}_{1} \mathrm{C}$ at least 2 times per year for diabetic patients [20]. The normal range of $\mathrm{HbA}_{1} \mathrm{C}$ test for nondiabetic people is between $4.2-6.2 \%$. In diabetic patients the recommended value by "International Diabetes Federation" and "American College of Endocrinology" is below $6.5 \%$, while acceptable level of ADA is below 7\% [20].

In the present study, diabetic obese patients had the lowest mean value of free testosterone compared with diabetic overweight and diabetic normomBMI as well as with healthy controls. The normal mechanism of the regulation of testosterone production in the gonadal healthy men depends on the hypothalamic - pituitary gonadal (HPG) axis. The defect in the hypothalamus or pituitary result in low testosterone levels because of insufficient stimulation of the Leydig cells. It is also associated with low or low-normal FSH and LH levels [21] . Moreover, low testosterone concentrations are known to occur in association with obesity and type 2 diabetes, several studies have addressed for the causes. It has been suggested that the increase in adipose tissue mass in obesity may result in increased aromatase activity and thus lead to a greater conversion of testosterone into estradiol. The estradiol negatively feeds back on the HPG system, reducing testosterone production in the Leydig cells. Increasing adipose tissue increases insulin resistance, which negatively impacts the Leydig cells as well as inhibiting the release of luteinizing hormone (LH) via the release of adipokines (inflammatory cytokines) such as tumor necrosis factor-a (TNF-a). Leptin, released in response to increased adiposity, also inhibits the release of LH via its effect on the release of gonadotropin-releasing hormone [22].

A decreased of free testosterone levels and increased $\mathrm{HbA}_{1} \mathrm{C}$ values in diabetic obese of the present study is consistent with the clinical and experimental studies demonstrated that diabetes caused altered gonadotrophic hormones, resulting in reduced testicular hormone secretion [23].

\section{References}

[1]. K. Ramesh Babu, K. Yogesh, H.L. Raghavendra, S.M. Kantikar and K.B. Prakash: Antidiabetic and histopathological analysis of fenugreek extract on alloxan induced diabetic rat, International Journal of Drug Development \& Research, 2010, 10-13.

[2]. Yadollah Harati, FACP, Diabetic Neuropathies: Unanswered Questions: Neurol Clin, 2007, 25, $303-317$.

[3]. Park KS. The search for genetic risk factors of type 2 diabetes mellitus. Diabetes Metab J 2011;35:12-22.

[4]. Powers KA, Rehrig ST, Jones DB. Financial impact of obesity and bariatric surgery. Med.Clin.North Am 2007;91:321-338. [PubMed: 17509381]ix. 
[5]. Ali, A.T., et al. (2011) Insulin resistance in the control of body fat distribution: A new hypothesis. Hormone me-tabolism Research, 43, 77-80.

[6]. Moreau, C., J. Bouyer,B. Ducot, A. Spira and R. Slama, 2010. When do involuntarily infertile couples choose to seek medical help . Fertility Sterility , 93: 737-744

[7]. Cooper TG, Noonan E, Von Eckardstein, etal." World Health Organization reference values for human. 4s5e.men characteristics." Hum Reprod! 2010;16(3): 231-

[8]. Klonoff-Cohen H. Female and male lifestyle habits and IVF: what is known and unknown. Hum Reprod Update 2005;11:179-203.

[9]. Mallidis C, Agbaje I, McClure N, Kliesch S. The influence of diabetes mellitus on male reproductive function : A poorly investigated aspect of male infertility. Urologe A. 2011;50:33-37.

[10]. La Vignera S, Calogero AE, Condorelli R, Lanzafame F, Giammusso B, Vicari E. Andrological characterization of the patient with diabetes mellitus. Minerva Endocrinol. 2009;34:1-9.

[11]. Kapoor D, Aldred H, Clark S et al. Clinical and biochemical assessment of hypogonadism in men with type 2 diabetes: Correlations with bioavailable testosterone and visceral adiposity, Diabetes Care 2007;30:911-17.

[12]. Bhasin S, Cunningham GR, Hayes FJ, et al. Testosterone therapy in men with androgen deficiency syndromes: an Endocrine Society Clinical Practice Guideline. J Clin Endocrinol Metab. 2010;95:2536-2559.

[13]. Grossmann M. Low testosterone in men with type 2 diabetes: significance and treatment. J Clin Endocrinol Metab. 2011;96:23412353.

[14]. Dandona P, Dhindsa S. Update: hypogonadotropic hypogonadism in type 2 diabetes and obesity. J Clin Endocrinol Metab. 2011;96:2643-2651.

[15]. Dandona P, Dhindsa S, Chaudhuri A, Bhatia V, Topiwala S, Mohanty P: Hypogonadotrophic hypogonadism in type 2 diabetes, obesity and the metabolic syndrome. Curr Mol Med 2008; 8: 816-828.

[16]. Strain GW, Zumoff B, Miller LK, et al: Effect of massive weight loss on hypothalamic-pituitary- gonadal function in obese men. J Clin Endocrinol Metab 1988; 66: 1019-1023.

[17]. Hill JW, Elmquist JK, Elias CF: Hypothalamic pathways linking energy balance and reproduction . Am J Physiol Endocrinol Metab 2008; 294:E827-E832.

[18]. Robertson, P.R., Harmon, J., Tran, O.P., Tanaka, Y. and Takahashi, H. (2003) Glucose toxicity in $\beta$-cell: Type 2 diabetes, good radicals gone bad, and the glutathione connection. Diabetes, 52, 581-587. doi:10.2337/diabetes.52.3.581.

[19]. Zhou, Y.P. and Grill, V. (1995) Long term exposure to fatty acids and ketones inhibits B-cell function in human pancreatic islets of Langerhans. Journal of Clinical En-docrinology and Metabolism, 80, 1584-1590. doi:10.1210/jc.80.5.1584

[20]. Gallagher EJ, LE Roith D, Bloomgarden Z. (2009). Review of hemoglobin A1C in the management of diabetes. J Diabetes. 1, 917.

[21]. Seftel A. Male hypogonadism. Part II: etiology, pathophysiology, and diagnosis. Int J Impot Res 2006; 18: $223-8$.

[22]. Dandona P, Dhindsa S, Chaudhuri A et al. Hypogonadotrophic hypogonadism in type 2 diabetes, obesity and the metabolic syndrome. Curr Mol Med 2008; 8: 816-28.

[23]. Ballester, J., Munoz, M.C., Dominguez, J., Rigau, T., Guinovart, J.J., Rodriguez-Gil, J.E., 2004. Insulin-dependent diabetes affects testicular function by FSH- and LHlinked mechanisms. J. Androl. 25, 706-719. 